\title{
LA VIRGEN DE LA O, DE LA PARROQUIA DE CHIPIONA, OBRA DEL ESCULTOR MANUEL GARCÍA DE SANTIAGO
}

\author{
POR FERNANDO AROCA VICENTI
}

La figura y obra de Manuel García de Santiago, como la de otros escultores del siglo XVIII sevillano, aún no ha sido estudiada. Este escultor y retablista, del que Ceán Bermúdez nos dice que fue discípulo de su padre, Bartolomé García de Santiago ${ }^{1}$, centra su actividad artística en la segunda mitad del setecientos. Quizás de su producción retablística se tienen más noticias que de su obra escultórica. De cualquier manera, la mayor parte de su trabajo aún no ha sido desvelado ${ }^{2}$.

La obra que aquí presentamos, hasta ahora inédita, ha sido localizada en la parroquia de Nuestra Señora de la O, en la localidad gaditana de Chipiona. Se trata de una imagen en madera policromada de la Virgen de la $\mathrm{O}$, titular de dicho templo, que se conserva en la capilla mayor, alojada en un baldaquino neoclásico que sustituye al primitivo retablo mayor ${ }^{3}$. La pieza fue encargada al escultor sevillano

1. J. A. Ceán Bermúdez: Diccionario histórico de los más ilustres profesores de las bellas artes en España. Madrid, 1800. T. II, p. 176.

2. El primer autor que ofrece algún dato de nuestro artista es el mencionado Ceán Bermúdez. A continuación Félix González de León menciona, aún bajo una óptica neoclásica de repudio hacia el barroco, algunas esculturas y retablos salidos de su mano, como el retablo de San Hermenegildo e imagen de San Gregorio Papa en la catedral; en el convento del Valle las imágenes de Santa Justa y Rufina procedentes de la catedral, (Noticia Artistica de todos los edificios públicos, sagrados y profanos de esta... ciudad de Sevilla. Sevilla, 1844. T. II, p. 35). Igualmente Antonio Sancho Corbacho menciona a Manuel García de Santiago como ensamblador, dudando si se trata de un hijo de Bartolomé, (Arquitectura barroca sevillana del siglo XVIII. Reedición, Madrid 1984, p. 286). Por último, estudios documentales recientes desvelan más datos del artista, (J. Prieto Gordillo: Fuentes para la historia del arte andaluz. Tomo XV. Noticias de escultura -1761-1780 - Sevilla 1995, pp. 86-91).

3. Tenemos constancia documental del desaparecido retablo mayor, construido por el retablista afincado en Jerez Matías José Navarro entre 1761-62 (Archivo Histórico Diocesano de Jerez de la Frontera. Chipiona, parroquia de la O. Fábricas. Visitas año 1764). Esta estructura es aún mencionada por Enrique Romero de Torres en su Catálogo Monumental de España. Provincia de Cádiz (1908-1909). Madrid, 1934, p. 498. 
Manuel García de Santiago, según contrato de 19 de octubre de 1785, así como su policromía al también sevillano José de Guevara, pintor ${ }^{4}$.

La escultura presenta un modelado correcto, destacando los pliegues de paños, con gran movimiento, que nos remite al pleno barroco sevillano. Sin embargo el tratamiento del rostro y cabellos evidencian incursiones del autor en fórmulas más clásicas. Cabe destacar el conjunto de querubines que, situados a los pies, alzan sus miradas encumbrando la figura de la Virgen. El tratamiento de estas cabezas de angelitos, de buena factura, se ajusta al esquema barroco dieciochesco.

Las labores de policromía han sido ejecutadas según los esquemas de la época: encarnaduras con brillo y un estofado no demasiado abigarrado.

Es interesante destacar la iconografía que presenta esta obra. El tema de la Esperanza o de la $\mathrm{O}$ deriva directamente de la Virgen Apocalíptica ${ }^{5}$. Su iconografía es una alusión directa a la fecundidad de María, mostrando su embarazo y en muchos casos la figura embrionaria de su hijo. García de Santiago opta en esta Virgen de la $\mathrm{O}$ de Chipiona por una iconografía tradicional, pero adaptándola a una época de piedad y fervor popular que requería un especial tratamiento plástico. Así, nos presenta a la Virgen sosteniendo el disco solar radiante con la figura del niño Jesús desnudo, que bien podría haber tomado de la miniatura de un cantoral del siglo XVI existente en la catedral de Sevilla ${ }^{6}$. Para contrarrestar el arcaísmo de la miniatura, el autor dota a la imagen de un elegante naturalismo -la Virgen evoca la composición de las inmaculadas barrocas-, sosteniendo el disco solar entre sus manos, y no pegado al vientre. La amplitud y movimiento de las telas oculta el embarazo de la Virgen y la figura embrionaria de Cristo, inserta en el radiante disco solar, se muestra como un popular tema del Niño Jesús, tan acorde con el gusto del momento. De esta forma nuestro autor consigue una aceptación directa de este tema iconográfico, retirado de muchos templos durante los siglos XVIII y XIX, debido a la crudeza con que en muchos casos fue tratado, con la consecuente escasa devoción que suscitaba ${ }^{7}$.

Hasta el momento desconocemos si existieron posibles huellas de este artista en otros escultores sevillanos. De cualquier manera, cabe destacar la presencia de sus dos hijos, también escultores, Juan y Juan Bartolomé ${ }^{8}$, en los que cabe suponer la influencia del padre. Tenemos noticias del primero de ellos a través de algunas obras realizadas para la catedral de Cádiz $^{9}$, dentro ya de un lenguaje más neoclásico.

4. Archivo Histórico Diocesano de Jerez de la Frontera. Chipiona, parroquia de la O. Fábricas. Visitas, años 1782-1792. El coste de la obra ascendió a 2.350 reales de vellón, repartidos entre 1.100 de la talla, 1.200 de la policromía y 50 para el transporte de la imagen de Sevilla a Chipiona.

5. M. Trens: María. Iconografía de la Virgen en el arte español. Madrid, 1952, p. 75.

6. Ibídem, p. 77.

7. Ibid., p. 75.

8. J. Prieto Gordillo, op. cit.

9. E. Hormigo Sánchez: "El arte en nuestra Catedral. Monumentos del Jueves Santo". Diario de Cádiz, jueves 4 de abril de 1985, p. 3. Además de la restauración de doce ángeles, Juan García de Santiago realizó cuatro serafines para la pirámide del monumento. Asimismo realizó la maqueta del mismo con sus figuras, que actualmente se muestra en el museo catedralicio. 


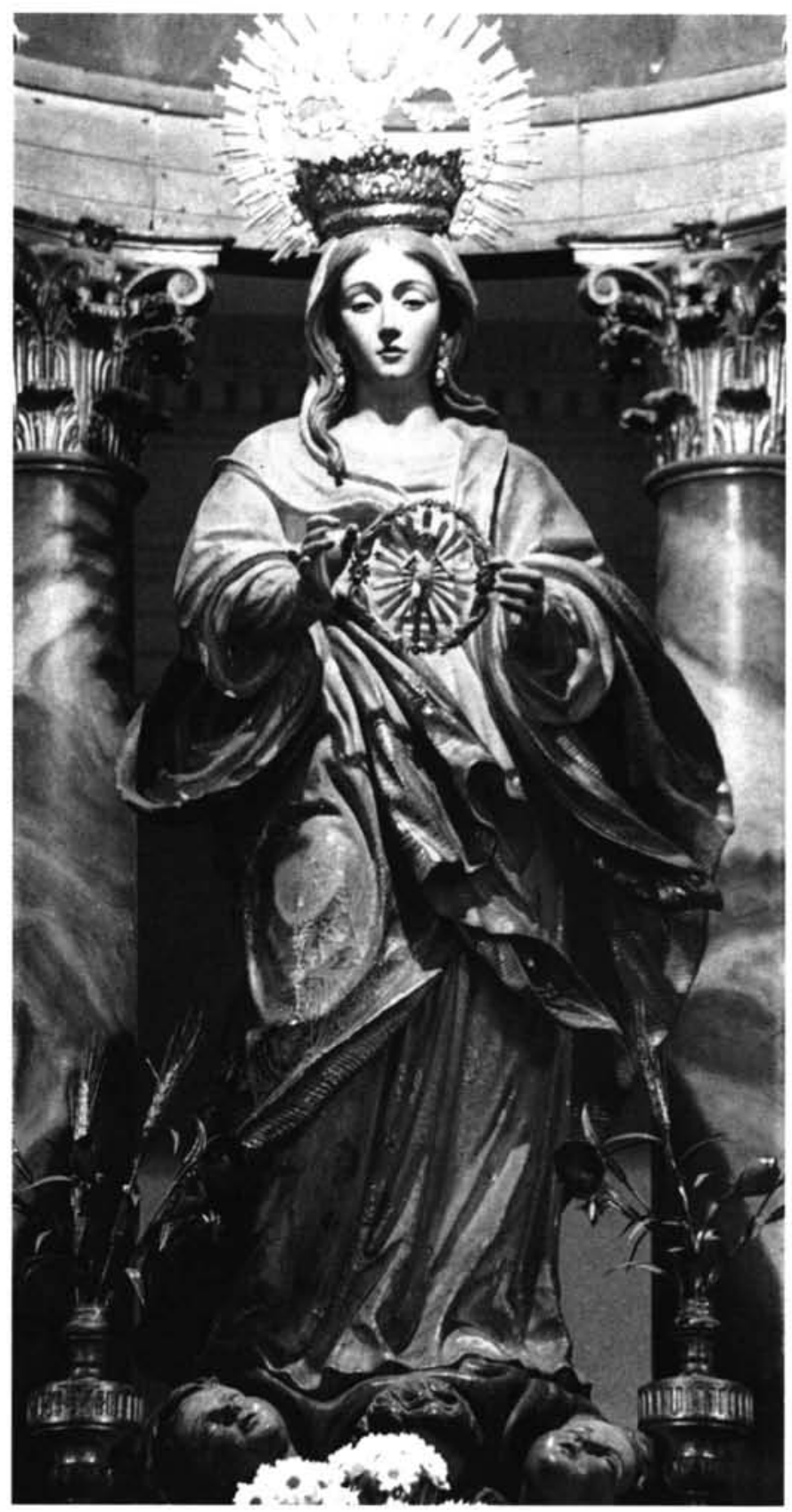

Lám. 1 